\title{
Aplikasi Layanan Informasi Berbasis Internet untuk Menumbuhkan Inklusi Sosial di Perpustakaan Daerah
}

\author{
Muhammad Usman Noor, M. Hum. \\ Manajemen Informasi dan Dokumen, Program Pendidikan Vokasi, \\ Universitas Indonesia \\ Email: usmannoor@ui.ac.id
}

\begin{abstract}
Abstrak
Perpustakaan umum memiliki kewajiban untuk memberikan layanan informasi yang inklusif, yang tidak membeda-bedakan siapapun dari atribut yang melekat pada dirinya seperti usia, suku, jenis kelamin, agama, kebangsaan, Bahasa, dan status sosial. Salah satu kriteria orang yang terekskusi adalah mereka yang tidak memiliki akses ke perpustakaan karena berbagai sebab, salah satunya adalah tidak memiliki waktu atau kesempatan ke perpustakaan karena jarak dan kesibukan sehingga mereka menjadi golongan yang tereksklusi. Perpustakaan Umum Daerah Jakarta memberikan layanan informasi melalui aplikasi iJakarta untuk menjangkau pemustaka yang terekslusi karena alasan tersebut. Penelitian ini bertujuan untuk mengetahui bagaimana layanan informasi perpustakaan melalui aplikasi iJakarta dapat menumbuhkan inklusi sosial dalam layanan perpustakaan. Penelitian menggunakan metode kualitatif dengan cara pengumpulan data melalui penelusuran bahan pustaka dan metode observatori. Temuan dari penelitian ini adalah layanan informasi melalui internet seperti iJakarta dapat membantu perpustakaan umum daerah Jakarta mendiseminasi layanannya. iJakarta yang merupakan layanan informasi yang tidak terbatas waktu dan ruang menjadi solusi masalah inklusi sosial tersebut, namun demikian masih perlu peningkatan fitur iJakarta secara menyeluruh seperti peningkatan kapabilitas temu kembali bahan pustaka. Penambahan fitur mengobrol langsung dengan pustakawan via iJakarta. Serta peningkatan stabilitas akses. iJakarta dengan penambahan dan penguatan fitur tersebut dapat menjadi model pengembangan layanan informasi yang inklusif dengan menggunakan bantuan teknologi informasi.

Kata Kunci: layanan informasi, inklusi sosial, perpustakaan umum, aplikasi perpustakaan, library 2.0
\end{abstract}

\begin{abstract}
Public libraries must provide information services that are inclusive, which do not discriminate anyone from the attributes inherent in them such as age, ethnicity, gender, religion, nationality, language, and social status. One criterion of people who are excluded is those who do not have access to the library for various reasons, one of which is not having the time or opportunity to the library because of distance and busyness so that they become excluded groups. Jakarta Regional Public Library provides information services through the iJakarta application to reach out to users who are excluded for this reason. This study aims to find out how library information services through iJakarta applications can foster social inclusion in library services. This research uses qualitative methods by collecting data through searching library materials and observatory methods. The findings of this study are that information services via the internet such as iJakarta can help Jakarta's regional public libraries disseminate their services. iJakarta, which is an information service that is not limited to time and space, is the solution to the social inclusion problem, however, it still needs to improve iJakarta's features as a whole, such as increasing the capability of retrieving library materials. Additional features chat directly with librarians via iJakarta. And improved access stability. iJakarta with the addition and strengthening of these features can be a model for developing information services that are inclusive by using information technology assistance.
\end{abstract}

Keywords: information services, social inclusion, public library, library apps, library 2.0 


\section{PENDAHULUAN}

Dalam kehidupan sosial bermasyarakat salah satu masalah yang timbul adalah adanya golongan masyarakat yang terekslusi. Masyarakat yang tereksklusi atau pemisahan golongan umumnya terjadi karena disebabkan oleh perbedaan atau kondisi yang dialaminya. Seperti yang sudah dimanifestokan oleh IFLA(1994) bahwasanya layanan perpustakaan umum harus menyetarakan akses tanpa memandang usia, suku, jenis kelamin, agama, kebangsaan, Bahasa dan status sosial. Layanan dan bahan pustaka spesifik harus disediakan bagi mereka yang, dengan beragam alasan, tidak dapat menggunakan layanan perpustakaa regular. Sebagai contoh orang yang hidup dalam lingkungan tertentu namun tidak bisa menggunakan Bahasa di daerah tersebut, orang dengan keterbatasan fisik atau orang yang tidak dapat ke perpustakaan karena sakit atau terpenjara. Lebih lanjut, sebagai contoh karena perbedaan warna kulit, suku, ras, agama, atau status sosial yang direpresentasikan dalam bentuk apakah dia kaya atau miskin, menjadikan suatu golongan menjadi tereksklusi. Sehingga muncul golongan di masyarakat yang tereksklusi atau berusaha dimarjinalkan dan tidak dianggap dalam masyarakat. Perpustakaan umum dibentuk untuk melayani kebutuhan informasi bahan bacaan seluruh lapisan masyarakat dari berbagai golongan tanpa memandang usia, ras, agama, status sosial ekonomi dan gender. Siapapun berhak mendapatkan dan menikmati layanan perpustakaan. Perpustakaan umum biasanya berdiri untuk melayani masyarkat dalam lingkup tertentu, umumnya tingkat kota atau provinsi. Perpustakaan umum daerah memiliki tugas dan fungsi sebagai pusat deposit daerah, pusat penelitian daerah, dan memberikan layanan informasi, pendidikan, dan ilmu pengetahuan kepada masyarakat luas. Sehingga sudah sewajarnya perpustakaan umum daerah memastikan layanannya mencakup seluruh masyarakat kota atau provinsi tersebut. Siapapun dia, apapun latar belakang sosialnya.

Eksklusi sosial sendiri adalah kondisi dimana ketidakmampuan suatu komunitas atau masyarakat untuk menghimpun semua golongan menjadi satu kesatuan secara utuh(Power \& Wilson, 2000). Ada pemisahan yang dilakukan di masyarakat baik itu melihat dari perbedaan pandangan, status sosial, gender atau apapun sehingga akhirnya menyebabkan ada golongan yang terpinggirkan dan termarginasilasi. Sehingga dapat disimpulkan bahwa inklusi sosial adalah kondisi dimana masyarakat dapat menyatukan seluruh komponen tanpa membedakan satu hal apapun. Semua sama dan bergabung dalam satu kesatuan. Terdapat beberapa jenis pengguna perpustakaan yang sering terekslusi sebagai contoh adalah etnis minoritas, pengungsi, pengguna berkebutuhan khusus, dan orang-orang yang tidak keluar rumah karena kondisinya(McMenemy, 2009). Sehingga dari kriteria tersebut, seseorang dapat menjadi tereksklusi karena kondisi yang dialaminya. Sebagai contoh, orang yang tidak dapat keluar 
rumah untuk pergi ke perpustakaan daerah karena berbagai sebab, semisal sakit sehingga tidak boleh keluar rumah, orang yang kesulitan mencapai perpustakaan karena kesibukannya, dan beberapa kondisi yang menyebabkan orang tersebut tidak dapat ke perpustakaan daerah. Sehingga karena kondisinya tersebut akhirnya orang tadi menjadi pengguna perpustakaan yang tereksklusi.

Dalam konteks pelayanan informasi, Perpustakan umum adalah badan yang dapat berkontribusi untuk mengubah situasi tersebut dan menawarkan ruang dan kesempatan untuk akses terhadap informasi dan pengetahuan yang memungkinka $\mathrm{n}$ mereka membangun identitas, membangun masyarakat, meningkatkan kualitas hidup dan mendukung pembelajaran sepanjang hayat(Talavera-ibarra \& Vega, 2015). Kondisi masyarakat tereksklusi tersebut kini banyak mendera masyarakat-pengguna potensial perpustakaan, terlebih di kota besar seperti Jakarta. Banyak masyarakat merasa enggan datang ke perpustakaan karena sulit mengakses lokasinya-dengan berbagai macam sebab, atau tidak memiliki waktu untuk datang ke perpustakaan karena kesibukannya. Padahal golongangolongan ini besar kemungkinan membutuhkan informasi karena mereka termasuk ke dalam masyarakat yang aktif. Sebagai contoh seorang yang tinggal di Jagakarsa dan bekerja di Senayan tentu tidak akan sempat ke Perpustakaan Daerah DKI Jakarta yang berada di Kuningan. Sehingga hal-hal semacam itu menjadikan seorang tadi tereksklusi dari perpustakaan. Tentu perpustakaan seharusnya mencoba pendekatan yang lain untuk mencapai pengguna potensial semacam ini. Kasus tersebut sangat mungkin terjadi di Jakarta, berdasarkan data dari BPS, penduduk Jakarta yang mencapai 5 juta orang menjadi tantangan tersendiri bagi Dinas Perpustakaan dan Kearsipan Provinsi DKI Jakarta (Dispusip Jakarta) untuk bisa mencapai semua pengguna tersebut sehingga tercipta inklusi sosial di perpustakaan. Jangan sampai hanya karena kondisi yang mengakibatkan pengguna tidak dapat ke perpustakaan secara fisik menjadikan pengguna itu tidak bisa atau tidak mendapat layanan perpustakaan sama sekali. Karena jika hanya mengandalkan kedatangan fisik ke perpustakaan, menurut data di Dispusip Jakarta pengunjung hanya berkisar 30-40 orang perhari. Sangat sedikit jika dibandingkan total penduduk Jakarta.

Perpustakaan DKI Jakarta memiliki semangat untuk membagikan layanan informasi kepada seluruh masyarakat Jakarta tanpa kecuali. Salah satu dasarnya adalah Pustakawan umumnya percaya bahwa kemampuan berempati sangat membantu dalam memberikan layanan golongan minoritas(Man, 2007). Adapun faktor yang dapat menumbuhkan inklusi sosial, adalah akses terhadap TIK dan informasi, tingkat Pendidikan, pekerjaan, status ekonomi, kesehatan dan gizi, lokasi serta akses terhadap transportasi umum (Train, Dalton 
and Elkin 2000; Wavell, Baxter, Johnson andWilliams 2002; Lockyer-Benzie 2004; Haggis dan Goulding 2003; Lockyer-Benzie 2004; Petr 2004; Benstead, Spacey dan Goulding 2004; Stilwell and Munyua 2009; Stilwell 2011a dalam Stilwell, 2016). Pengguna TI dapat menjadi sarana bagi perpustakaan untuk menggapai atau memberikan layanan kepada masyarakat yang rentan tereksklusi tersebut, seperti yang juga diutarakan Muddiman dkk (2000) bahwa teknologi informasi dapat dimanfaatkan untuk memenuhi kebutuhan golongan yang tereksklusi. Meskipun Penggunaan IT dalam menumbuhkan inklusi sosial masih menjadi perdebatan, apakah itu malah menjadi penghambat atau pendorong terjadinya inklusi sosial. Namun diketahui bahwa area perkotaan lebih membutuhkan layanan TI yang lebih memadai, untuk mendorong tumbuhnya lingkungan cerdas. Lingkungan cerdas tersebut dapat tercipta untuk memastikan terjadinya inklusi sosial dalam skala yang besar(Coetzee \& Olivrin, 2012). Salah satu layanan informasi yang diberikan oleh Dispusip Jakarta untuk mendukung hal tersebut adalah dibangunnya aplikasi iJakarta. iJakarta sendiri adalah layanan informasi berbasis aplikasi gawai yang dapat digunakan oleh pengguna untuk mengakses dan membaca koleksi perpustakaan melalui gawai. iJakarta dapat digunakan oleh seluruh masyarakat Jakarta dengan menggunakan gawai. Penelitian ini bertujuan untuk mengetahui bagaimana layanan informasi perpustakaan melalui aplikasi iJakarta dapat menumbuhkan inklusi sosial dalam layanan perpustakaan. Harapannya penelitian ini dapat memberikan perspektif baru dalam melayankan informasi di era industry 4.0 dimana semua semakin terhubung namun tetap mengedepankan aspek sosio humaniora bahwa kenyataan pustakawan yang dilayankan adalah manusia.

\section{METODE}

Penelitian ini menggunakan metode kualitatif dengan metode pengumpulan data melalui penelusuran bahan pustaka dalam pengumpulan data melalui metode observatori. Metode observatori yang dimaksud adalah penulis, sebagai pemustaka yang juga terekslusi karena ketiadaan waktu ke perpustakaan umum, menjadi pengguna aplikasi iJakarta selama 2 bulan terakhir dari akhir tahun 2018 hingga awal tahun 2019. Proses yang dilakukan dalam penelitian kali ini, pertama penulis melakukan studi literature mengenai layanan informasi berbasis aplikasi dan inklusi sosial yang dibangun oleh perpustakaan. Tahap berikutnya menghubungkan literature tersebut dengan pengalaman menjadi pengguna aplikasi iJakarta untuk dilakukan analisis. Tahap ketiga adalah menyusun data-data yang telah didapatkan. Sebagai pendukung data tambahan, penulis juga melakukan wawancara tidak terstruktur pada 
pustakawan Dispusip Jakarta. Dalam penelitian kali ini memiliki keterbatasan cakupan penelitian. Golongan masyarakat terekslusi yang dimaksud adalah mereka yang merupakan warga DKI Jakarta namun memiliki kesulitan mengakses layanan informasi ke perpustakaan secara langsung karena beragam hal, sehingga perlu diberikan akses informasi melalui cara lain seperti penyediaan informasi melalui internet atau aplikasi.

\section{HASIL DAN PEMBAHASAN}

Pemustaka yang terekslusi jika berdasarkan literatur, pengguna yang tereksklusi sebabnya macam-macam. Salah satunya adalah mereka yang tidak dapat keluar rumah disebabkan beberapa hal antara lain, harus menjaga rumah karena suatu hal, karena memiliki penyakit sehingga sulit untuk keluar rumah, dan lain sebagainya. Perpustakaan umum daerah sudah sepantasnya tetap memperhatikan pengguna yang semacam ini, demi terciptanya pengguna yang terinklusi. Untuk dapat mencapai pengguna yang tidak dapat keluar rumah dan pergi perpustakaan karena berbagai macam sebab tersebut dapat dibantu dengan menggunakan fasilitas web perpustakaan yang memadai. Banyak cara yang bisa ditempuh oleh perpustakaan daerah untuk mencapai pengguna-pengguna yang semacam itu. Yaitu pengguna yang tidak mampu atau memiliki keterbatasan dalam mengunjungi perpustakaan.

Perpustakaan daerah bisa mencoba meraih pengguna tersebut dengan menggunakan cara tradisional yaitu dengan membuka layanan perpustakaan keliling ke lingkungan perumahan hingga cara yang menggunakan teknologi jaringan. Perpustakaan keliling, layanan perpustakaan bergerak ini dianggap sebagai sarana utama untuk mencapai suatu komunitas. Menurut Orton (1980:10 dalam (McMenemy, 2009)), perpustakaan keliling sudah dilakukan dari tahun 1859 di Inggris, dilakukan untuk mencapai golongan pekerja, sehingga golongan pekerja pada saat itu bisa menikmati layanan perpustakaan. Namun dengan bantuan teknologi, menghadirkan layanan tidak melulu harus mendatangi pengguna secara fisik, karena sebagaimana kita tahu teknologi jaringan sudah semakin maju, menghasilkan berbagai konsep baru dalam perpustakaan. Antara lain konsep Library 2.0. Library 2.0 sendiri adalah suatu konsep yang membuat perpustakaan di web tidak hanya sekadar etalase namun juga memiliki daya interaksi di dalamnya. Sebagai contoh, pengguna dapat berinteraksi dengan pustakawan melalui layanan chat, pengguna dapat memberikan komentar mengenai koleksi perpustakaan, pengguna dapat menggunakan web perpustakaan untuk peminjaman atau akses ke sumber informasi. Layanan-layanan demikian dapat diakses dari rumah melalui internet, 
sehingga masyarakat yang tidak dapat ke perpustakaan tetap dapat menikmati layanan perpustakaan umum di daerahnya.

Salah satu layanan perpustakaan yang dapat menekel hal tersebut adalah layanan yang dapat diakses dari berbagai tempat. Dispusip Jakarta bekerja sama dengan PT. Woolu Aksara Maya meluncurkan iJakarta untuk mengakomodir hal tersebut pada akhir tahun 2015. iJakarta adalah aplikasi layanan perpustakaan berbasis aplikasi yang bisa diakses melalui gawai bersistem operasi android dan iOS. Konsep iJakarta pada dasarnya sama dengan konsep perpustakaan konvensional pada umumnya, hanya yang berbeda adalah bentuknya yang digital. Dengan iJakarta, pustakawan tidak perlu khawatir dengan buku yang tidak dikembalikan pengguna karena metode peminjaman dan pengembalian buku diatur dalam sistem, selain itu dalam hal preservasi koleksi tentu bukanlah menjadi masalah karena buku tidak akan tersobek ataupun tercoret. Salah satu alasan dibangunnya iJakarta adalah efisiensi biaya. Biaya yang dibutuhkan untuk membangun perpustakaan di banyak tempat di Jakarta dianggap kurang efisien dan mahal. Sedangkan model distribusi koleksi dengan menggunakan aplikasi dianggap dapat menjadi solusi dan memudahkan pengguna dalam mengakses perpustakaan.

iJakarta diluncurkan untuk memenuhi kebutuhan informasi masyarakat Jakarta tanpa harus datang ke perpustakaan. Untuk dapat mengakses dan menggunakan iJakarta secara utuh maka pemustaka harus mendaftar terlebih dahulu. Pendaftaran tidak mengharuskan atau dilakukan verifikasi tertentu, sehingga masyarakat yang tidak memiliki KTP Jakarta pun tetap bisa mengakses iJakarta. Keuntungan menjadi anggota iJakarta antara lain dapat meminjam koleksi yang ada di iJakarta. Peminjaman buku melalui iJakarta dilakukan secara mandiri dan automatis melalui menu collection. Anggota bisa meminjam buku maksimal 3 judul dalam satu waktu, dengan durasi peminjaman selama 1 minggu. Setelah 1 minggu maka secara otomatis buku yang kita pinjam tidak dapat diakses, kecuali kita meminjamnya kembali. Adapun buku yang dipinjam hanya dapat dibaca melalui iJakarta sehingga tidak bisa diakses dengan menggunakan aplikasi pembuka dokumen seperti PDF Reader dan sejenisnya.

iJakarta memiiki beragam fitur, beberapa fitur utama dari iJakarta antara lain: Connect with Face-book dan email merupakan fitur yang ada di iJakarta yang dapat digunakan pengguna untuk mendaftarkan dirinya melalui akun facebook dan email. Profile Setting, pengguna dapat mengatur profil akunnya. Adapun yang dapat diatur antara lain foto, username, alamat e-mail, alamat, password, dan biografi. Di dalamnya juga terdapat fitur Notifikasi dan Inbox sebagai pemberitahuan dan sarana percakapan dengan pengguna lain. Status Badges Fitur ini merupakan fitur untuk level baca pengguna. Terdapat beberapa level 
baca di iJakarta yaitu Newbie, Bookworm, dan Socializer. ePustaka, adalah kumpulan dari instansi atau penerbit yang telah bekerjasama dengan iJakarta. Book Detail pada book detail akan muncul deskripsi bibliografi buku seperti judul buku, pengarang, ISBN, penerbit, tanggal terbit, rating buku, dan harga buku, sinopsis, want list (list yang menginginkan buku tersebut), is read (yang sedang membaca buku tersebut), has read (yang telah selesai membaca buku tersebut), dan review. Share merupakan fitur dalam iJakarta untuk berbagi info mengenai detail buku. Pengguna dapat membagikan info detail buku melalui facebook, twitter, e-mail dan recommend. Share recommend digunakan untuk membagikan informasi buku dengan cara mengirimkan notifikasi ke pengguna yang sudah saling mengikuti. Shelf merupakan fitur untuk kumpulan koleksi buku yang sudah dimiliki, koleksi yang diinginkan, serta koleksi yang sudah selesai dibaca. e-reader e-reader adalah fitur untuk membaca $e$ book dengan format EPUB yang dilengkapi dengan TOC (Tabel Of Content) di mana pengguna dapat melihat daftar isi e-book, Change Font Style (mengganti jenis huruf), Change Font Type (mengganti tipe huruf), Line Spasing (mengatur jarak antar baris), Change Theme (mengubah tema), Bookmark, Search (mencari kata atau kalimat dalam e-book), mengatur pencahayaan ketika membaca $e$-book, membuat catatan, dan merekomendasikan e-book yang dibaca ke pengguna lain. Feeds Feed merupakan kumpulan informasi yang bersifat publik. Adapun informasi yang termasuk ke dalam feed seperti followers yang menambah buku, followers yang bergabung ePustaka, perubahan Status Badges User, buku baru yang ditambahkan di e-pustaka yang diikuti, pemberitahuan dari administrator iJakarta. iJakarta Offline Aplikasi ini dapat digunakan dalam kondisi terkoneksi ini internet ataupun tidak(iJakarta, 2015). Penggunaan tanpa koneksi internet dapat dilakukan hanya untuk membaca buku, jika buku yang akan dibaca telah diunduh. Donation Box Aplikasi ini memungkinkan pengguna untuk membeli lisensi buku yang ada di koleksi iJakarta sehingga menambah jumlah eksemplar kopi yang dapat dipinjam oleh pengguna lain.

Koleksi buku pada aplikasi iJakarta berbentuk e-book dengan format PDF atau EPUB. Jumlah koleksi yang dimiliki oleh iJakarta berjumlah 5940 buku (tahun 2019). Dalam iJakarta koleksi dikelompokkan dalam Dalam iJakarta koleksi dikelompokkan dalam 109 Kategori, antara lain beberapa diantaranya yaitu Agama \& Spiritual, Arsitektur, Bahasa, Bahasa Asing, Biografi, Biografi, Otobiografi, Bibliografi, Bisnis, Bisnis \& Ekonomi, Budaya, Budidaya, Busana, Cerpen, Drama, Fiksi, Fiksi Remaja, Filafat, Fotografi, Game, Gaya Hidup dan Hiburan, Geologi dan Geografi, Hewan, Hukum, Hukum \& Politik, Humaniora, Humor, Ilmu Administrasi, Ilmu Pengetahuan \& Budaya, Interior \& Eksterior, Kamus, Kedokteran \& Medis, Keluarga, Kerajinan \& Hobi, Kesehatan, Kesehatan \& 
Kepribadian, Kesehatan dan Obat-obatan, Komik, Komputer \& Internet, Komunikasi, Komunikasi \& Jurnalis, Kriminal, Kritik Sastra, Kuliner, Manajemen, Matematika, Memasak, Motifasi \& Inspirasi, Musik, Non Fiksi, Non Fiksi Remaja, Olahraga \& Rekreasi, Panduan, Pendidikan, Pendidikan dan Permainan, Pendidikan Karakter, Puisi, Referensi, Rumah, Sains \& Teknologi, Sastra \& Budaya, Sastra Koleksi, Sejarah, Self-Help, Seni \& Budaya, Seni, Hiburan, \& Pertunjukan, Sosial \& Politik, Transportasi, Tubuh, Pikiran, dan Umum. Penggunaan subjek sebagai salah satu metode pencarian dirasa kurang handal karena tidak mengacu pada klasifikasi subjek tertentu. Terdapat subjek yang dirasa tumpang tindih dan seharusnya dapat dikolokasikan menjadi satu subjek yang lebih umum, seperti subjek Agama. Subjek besar seperti Hukum dan Politik dijadikan satu subjek bernama "Hukum \& Politik" sehingga membuat presisi pencarian menjadi lebih rendah. iJakarta dapat menggunakan konsep pencarian Pasca Laras, dimana pemustaka yang menentukan titik akses dan penggabungan subjek yang diinginkan sehingga menghasilkan hasil pencarian yang lebih presisi.

Pustakawan Dispusip Jakarta harus lebih aktif dalam menyelesaikan masalah layanan berbasis inklusi ini. Langkah yang bisa ditempuh antara lain, menargetkan promosi layanan melalui iJakarta melalui komunitas yang sebenarnya membutuhkan informasi namun sulit akses ke perpustakaan. Karena salah satu langkah yang dapat menyelesaikan masalah eksklusi sosial antara lain secara rutin mendekati komunitas yang terekslusi, bekerja sama dengan bidang sosial yang menangani masalah tersebut dan bersikap proaktif dalam mendekati komunitas tersebut (Muddiman et al., 2000) Data dari Asosiasi Penyelenggara Jasa Internet Indonesia(APJII) menunjukkan bahwa pada tahun 2017(Asosiasi Penyelenggara Jasa Internet, 2018) 44,16\% pengakses internet di Indonesia menggunakan gawai untuk mengakses internet. Sehingga peluang iJakarta untuk menjadi sarana diseminasi layanan perpustakaan bagi golongan yang terekslusi di Jakarta sudah tepat. Peluang lainnya adalah Internet sudah menjadi barang umum di kalangan masyarakat perkotaan seperti Jakarta. Internet juga bukan barang mewah lagi, bahkan sudah banyak yang hidupnya sangat tergantung kepada Internet, jaringan internet di rumah-rumah pun sudah banyak. Bahkan orang kini dapat mengakses internet dari perangkat komunikasi yang mereka miliki seperti handphone, smartphone atau tabletnya. Sehingga potensi untuk memberi layanan melalui internet sangat terbuka lebar karena memang masyarakatnya sendiri sudah siap dengan internet.

Namun demikian hingga Februari 2019 iJakarta telah diunduh lebih dari 100.000 kali, jumlah tersebut jika dibandingkan dengan penduduk DKI Jakarta yang berjumlah 10,17 juta 
jiwa (Badan Pusat Statistik, 2017) sangatlah kecil, hanya kurang lebih $1 \%$ dari total penduduk. Sehingga Dispusip Jakarta perlu menyusun strategi layanan yang lebih tepat untuk menggapai pengguna. Sehingga layanan melalui iJakarta dapat menyentuh pemustaka yang tereksklusi ini sehingga kemudian mereka menjadi bagian dalam inklusi sosial terutama terkait layanan perpustakaan. Lebih lanjut, strategi promosi untuk meluaskan layanan ini Dispusip Jakarta harus mempertimbangkan kebutuhan khusus dari golongan-golongan yang dianggap tereksklusi. Perpustakaan daerah harus mampu mengidentifikasi golongan mana yang termasuk atau dianggap tereksklusi. Dalam hal ini iJakarta dipromosikan dengan beragam kegiatan dan saluran seperti pemilihan duta iJakarta, sosialisasi program melalui Instagram, twitter, dan facebook. Saluran sosial media yang digunakan sebagai promosi terpantau dikelola dengan baik dalam hal keterbaruan konten. Jika masalah keterbaruan konten sudah berjalan baik, maka pemilihan konten promosi di sosial media dapat diupayakan menyesuaikan dengan karakteristik pemustaka di Jakarta yang memiliki kesulitan mengakses perpustakaan karena lokasi dengan menampilkan kemudahan akses informasi melalui iJakarta dari mana saja dan tidak terbatas waktu, harapannya calon pemustaka lebih tertarik untuk mengunduh iJakarta di gawainya.

iJakarta meskipun memiliki fasilitas chat namun pengguna hanya bisa melakukan chat sesame pengguna. Tidak tersedia fitur chatting dengan pustakawan. Penting adanya fitur yang memungkinkan komunikasi 2 arah antara pengguna dengan perpustakaan. Pengguna bisa mendapatkan layanan informasi yang lebih memadai, perpustakaan pun dapat mengetahui apa yang menjadi kebutuhan penggunanya. Komunikasi 2 arah yang terjadi di iJakarta dapat juga menjadi salah satu bentuk layanan perpustakaan yang partisipatif, dimana perpustakaan membuka diri untuk menjadikan pengguna sebagai inti dari layanannya, atau dengan kata lain pelayanan berorientasi pada pengguna. Namun demikian, hal ini terjadi karena memang dalam operasional pelaksanaan iJakarta, pihak Dispusip Jakarta menyerahkan sepenuhnya langsung kepada Woolu Aksaramaya untuk operasionalnya. Pihak Dispusip Jakarta hanya bertanggung jawab pada seleksi dan pengadaan konten yang akan dilayankan melalui aplikasi iJakarta. Sehingga tidak ada pustakawan dispusip bagian layanan yang in-charge pada iJakarta. Hal ini cukup disayangkan karena sebagai bentuk layanan, iJakarta seharusnya dapat memberikan layanan lebih kepada penggunanya dengan sentuhan dari pustakawan dispusip.

Adapun jika memang belum ada pustakawan Dispusip Jakarta yang secara khusus mengelola iJakarta secara langsung namun terdapat beberapa langkah yang bisa dilakukan oleh DISPUSIP Jakarta terkait layanan perpustakaan iJakarta. Antara lain memperkuat koordinasi Dispusip Jakarta dengan Wolu Aksara selaku pengelola iJakarta dalam 
memberikan layanan informasi berupa peminjaman dan beragam fitur di dalam iJakarta. iJakarta perlu ditambahkan fitur komunikasi langsung dengan pengembang atau pustakawan sehingga bisa memberikan komunikasi dua arah seperti layanan chat dengan pustakawan dan memungkinkan pengguna memberi masukan ke perpustakaan. Sehingga diharapkan terjadi interaksi antara pengguna dan pustakawan yang pada akhirnya menjadikan semua masyarakat merasa menjadi bagian dari perpustakaan dan mendapat manfaat dari perpustakaan.

Mengembangkan layanan perpustakaan berbasis online melalui aplikasi sebenarnya jika dipandang dari sisi ekonomis juga lebih menguntungkan. Biaya pengembangan aplikasi memang membutuhkan dana besar namun jika dipandang dari sudut investasi akan menjadi lebih murah, karena biaya tersebut hanya dikeluarkan besar ketika awal. Sedangkan untuk operasional jauh lebih murah dari biaya pengembangannya. Pada layanan informasi berbasis online pustakawan cukup menjawab pertanyaan atau memberi layanan melalui mejanya masing-masing. Namun demikian dalam berbagai pengalaman dan kasus layanan berbasis teknologi di Indonesia. Masih terdapat banyak layanan berbasis Library 2.0 pada akhirnya layu sebelum berkembang akibat tidak adanya pustakawan yang mengelola layanan tersebut. Walaupun library 2.0 berbasis teknologi, namun sentuhan manusia diperlukan untuk mengisi dan mengelolanya(Noor, 2018). Sehingga perlu komitmen dari dispusip untuk terus mempertahankan dan memelihara iJakarta. Menilik dari masukan dan komentar para pemustaka iJakarta di platform Google Play, terlihat kebanyakan dari mereka sangat terbantu dengan adanya iJakarta karena dapat mengakses koleksi perpustakaan dengan mudah, namun dalam beberapa bulan terakhir semenjak September 2018 cukup banyak keluhan mengenai stabilitas dari aplikasinya, pemustaka sering mengalami masalah aplikasi iJakarta tertutup secara tiba-tiba ketika sedang digunakan. Dispusip dan pihak pengembang Aksaramaya harus peka dengan keluhan seragam ini dan berusaha segera untuk memperbaiki atau memberikan pembaharuan aplikasi.

\section{PENUTUP}

\section{Simpulan}

Sehingga pada akhirnya, inklusi sosial terbentuk di perpustakaan daerah tidak melulu menyoal perilaku non diskrimatif kepada suatu ras, gender, golongan atau status tertentu. Cerminan inklusi sosial lebih kompleks dari sekadar perbedaan ras, gender, golongan atau status tersebut. Kondisi eksklusi sosial juga bisa terjadi karena kondisi yang akhirnya menyebabkan mereka tereksklusi. Kondisi demikian seringkal tidak nampak, kalah dari isu mengenai perbedaan ras, gender, golongan atau status. Padahal di balik itu ada pengguna- 
pengguna yang tereksklusi karena keadaan sehingga tidak dapat ke perpustakaan dan pada akhirnya tidak dapat menggunakan layanan perpustakaan. Celah ini diisi dengan layanan iJakarta oleh Dispusip Jakarta. iJakarta yang merupakan layanan informasi yang tidak terbatas waktu dan ruang menjadi solusi masalah inklusi sosial tersebut, namun demikian masih perlu peningkatan fitur iJakarta secara menyeluruh seperti peningkatan kapabilitas temu kembali bahan pustaka. Penambahan fitur mengobrol langsung dengan pustakawan via iJakarta. Serta peningkatan stabilitas akses. iJakarta dengan penambahan dan penguatan fitur tersebut dapat menjadi model pengembangan layanan informasi yang inklusif dengan menggunakan bantuan teknologi informasi.

Masih minimnya penggunaan iJakarta oleh masyarakat Jakarta menunjukkan bahwa iJakarta perlu strategi promosi yang lebih tepat sasaran. Salah satunya dengan mendekati komunitas dan menyesuaikan promosi dengan target pemustaka. Harapannya, semakin banyak pengguna yang merasakan layanan informasi melalui iJakarta ini diharapkan masyarakat menjadi lebih sadar akan keberadaan perpustakaan. Jika masyarakat telah berkembang kesadarannya maka promosi dari mulut ke mulut akan terjadi secara viral dan cepat. JIka sudah demikian, iJakarta akan dirasakan manfaatnya bagi masyarakat Jakarta dan tercipta suatu masyarakat Jakarta yang berbasiskan informasi. Penelitian ini memiliki keterbatasan antara lain, golongan terekslusi yang dimaksud dalam penelitian ini adalah mereka yang memiliki keterbatasan dalam hal mengakses perpustakaan secara langsung. Sehingga penelitian untuk melihat seperti apa iJakarta dalam merangkul pengguna yang memiliki masalah keterbatasan fisik, atau kemampuan khusus sangat terbuka untuk kemudian diteliti.

\section{DAFTAR PUSTAKA}

Asosiasi Penyelenggara Jasa Internet. (2018). Penetrasi \& Perilaku Pengguna Internet Indonesia Survey 2017. Teknopreneur (Vol. 2018). Jakarta.

Badan Pusat Statistik. (2017). Jumlah Penduduk DKI Jakarta Menurut Jenis Kelamin dan Kelompok Umur tahun 2015. Jakarta.

Coetzee, L., \& Olivrin, G. (2012). Inclusion Through the Internet of Things. In F. A. A. Cheein (Ed.), Assistive Technologies. IndotechOpen.

iJakarta. (2015). How to iJakarta.

International Federation of Library Associations and Institutions. (1994). IFLA/UNESCO $\begin{array}{lllll}\text { Public Library } & \text { Manifesto } & \text { Retrieved }\end{array}$ 
https://www.ifla.org/publications/iflaunesco-public-library-manifesto-1994

Man, T. H. (2007). Social inclusion and public libraries: Is the ability to empathise an essential attribute for community librarians to better serve their ethnic minority users? A case study of Highfield Library and its Chinese community. University of Sheffield.

McMenemy, D. (2009). The Public Library. London: Facet Publishing.

Muddiman, D., Dutch, M., Linley, R., Durrani, S., Pateman, J., \& Vincent, J. (2000). Open to All? The Public Library and Social Exclusion Volume One: Overview and Conclusions. West Yorkshire.

Noor, M. U. (2018). Pemanfaatan Library 2.0 di Perpustakaan Perguruan Tinggi di Indonesia: Studi Kasus 150 Universitas terbaik di Indonesia versi Webometrics tahun 2016. Jurnal Ilmu Perpustakaan Dan Informasi, 2(2), 184-193.

Power, A., \& Wilson, W. (2000). Social exclusion and the future of cities. LSE STICERD

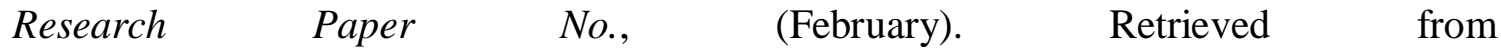
http://papers.ssrn.com/sol3/papers.cfm?abstract_id=1158926

Stilwell, C. (2016). The public library as institutional capital: Towards measures for addressing social inclusion and combating poverty. International Development, 32(1), 44-59. https://doi.org/10.1177/0266666914525063

Talavera-ibarra, A. M., \& Vega, A. de la. (2015). Opportunity for all : Three Social Inclusion Experiences in Peru's Public Libraries. In IFLA WLIC 2015. Cape Town: IFLA. 